\title{
CSR INFLECTIONS: AN OVERVIEW OF CSR PRACTICES ON FINANCIAL PERFORMANCE BY PUBLIC LISTED COMPANIES IN MALAYSIA
}

\author{
Norwazli Bt Abdul Wahab, Noryati Bt Ahmad, Haslinda Bt Yusoff \\ Faculty of Business Management, Faculty of Accountacy, Universiti Technology of MARA,
}

\begin{abstract}
Of late, there has been growing demand for companies to intensify its corporate social responsibility (CSR). It is no longer one of the responsibilities of the companies but has become the responsibility of companies to give back to the society in which it has been operating and making huge profit. Unfortunately there appears to be a wide gap between the level of CSR awareness between companies from developed countries and those from the developing companies. Companies from developed countries have higher CSR level of awareness and faced no difficulty in disclosing their CSR activities relatively to the companies in the developing countries (including Malaysia). Thus, the aim of this paper is to examine the level of CSR disclosure of consumer products and trading and services industries from Malaysia. In addition, the study also would like to ascertain if the level of CSR disclosure influences the performance of the company in terms of its return on asset (ROA) and firm value (Tobin's Q). The study starts with the development of CSR disclosure index and using the index to determine if company's performance is related to its contribution to the society. Panel data is used to achieve the second objective. Findings of the study provide positive, negative and insignificant results between CSR activities on the company performance.
\end{abstract}

Keywords: Corporate social responsibility, corporate social responsibility disclosure (CSRD), corporate financial performance (CFP), content analysis

\section{INTRODUCTION}

There has been a rapid evolution on Corporate Social Responsibility (CSR) over the last few decades among companies. Today, the investors and stakeholders are paying attention not only to the bottom line but also company's contribution towards the society. As a result, the companies are expected to be more responsible in doing their business. In line with this development, more and more companies have taken CSR seriously and incorporate this element in corporate strategy. They realized that embedded CSR as part of their corporate strategy has alleviated their image and competitive advantage. These practices have become a significant aspect to compete locally and globally. Based on the literature review, as for developed countries, CSR practices are considered as a business strategy in order to improve the company's financial performance. According to Kay (1993), there are three reasons for CSR to be pertinent to business, (1) provides input to strategy as it provides an understanding about the different key elements in the business milieu, (2) a support for the value of chain and value creation activities and (3) a middle-of-the- road management task that to be supervised as well as any other business process. This is supported by Ruf, Muralidhar, Brown, Janney and Paul (2001) stating that "the dominant stakeholder group, shareholders, financially benefit

Corresponding author's email: nor_1143@yahoo.com 
when, management meets the demands of multiple stakeholders. They conclude that by improving subsequent corporate social performance (CSP), it is positively related to sales growth for the current and subsequent years. Perhaps, it generates short term benefits and also create potential for the long term benefits. Conversely, Mahoney and Roberts (2007) argued that besides improving the financial performance of companies, CSR practices also attracts the positive response from institutional investors. However, although slowly gaining attention, CSR practices among companies in developing countries have been rather slow or lacking. Most of these companies viewed CSR as additional costs and found it not to be relevant to their business strategy.

To what extent have Malaysian companies been involved in CSR practice? In general, corporate social responsibility disclosure (CSRD) has been used as a proxy to CSR studies. It discloses information of what the companies have contributed and plan for future to the welfare of the society. Usually the information will be stated in a social responsibility report and publishes in company's websites or annual report of public listed companies (Zainuddin and Nasruddin, 2006; Mohamed Zain and Janggu, 2006). Additionally, their concern whether CSRD is positively or negatively influence the shareholders' insight has led companies to think not only their financial performance but also their environmental and societal performance. Therefore, to attract investors, companies begin to coordinate their CSR activities and disclose more information concerning CSR activities in annual report and stand-alone sustainability report. This triggers interest among researchers to conduct studies on the relationship between CSRD and company financial performance (CFP) (Mustaruddin, Norhayah and Rusnah, 2011; Nor Hawani, Mustaffa and Norhasnah, 2011; Shveta and Sandhu, 2010; Choi, Kwak and Choe, 2010; Mustaruddin, 2009). However, empirical results on the relationship between CSRD and company's financial performance have been inconclusive where some studies show positive results, others have negative relationship between the two variables and there are those that produced mixed relationship. The validity of the findings on the direction of the impact of CSR activities on future corporate performance is continuously being questioned (Margolis and Walsh, 2003; Orlitzky et al, 2003) due to various measures over a substantial time span for instance how different measures of socially responsible practices can generate better financial performance.

In Malaysia, starting on $31^{\text {st }}$ December 2007, it is compulsory for public listed companies in Malaysia to disclose their CSR activities. The focus of the CSR practices are mainly on four areas namely; community, environment, marketplace and workplace with no order of priority since Bursa Malaysia acknowledged the diversity of those listed companies. Nevertheless these guidelines are flexible and require minimum disclosure in their report. There is no detail specific information to be disclosed and the amount of disclosure required by the companies but rather gives companies the flexibility to provide information relating to their CSR activities. Since involvement of CSR practices are still relatively new among listed companies in Bursa Malaysia, it is therefore interesting to investigate the extent of CSR disclosure that were made by these companies and which activities are mostly been disclosed. In addition, this study would like to determine the relationship between CSR disclosure and financial performance. The area of study is considered relevant since the topic has created an attention to several organizations and the Malaysian government particularly seeing that CSR is the national agenda (Othman, Darus and Arshad, 2011).

\section{REVIEW OF PREVIOUS RELATED STUDIES}

Corresponding author's email: nor_1143@yahoo.com 
There motive behind corporate social responsibility (CSR) goes beyond the financial gains of company. CSR attempts to promote socially beneficial activities into the business that would ensure sustainability and survivorship of the company. Unfortunately very few companies are willing to engage in social responsibility activities and disclosure. For those who are championing the CSR practices do so because they realize the positive impacts on their products, services and other activities. Highlighted by Tsoutsoura (2004), being socially responsible should have bottom-line benefits in order to be sustainable. This include the increased in the productivity has resulted from the improved working conditions and labour practices. For instance, by implementing simple measures such as reducing wrapping material and planning optimal route for delivery trucks are not only could reduce a company's operating costs but also as a motivation for companies to increase their CSR activities as it helps to protect the environment. Furthermore, Jenkins (2005) emphasized that brand image and reputation is greater in companies that implement CSR practices than those who are not, or in socially irresponsible companies since the customers and suppliers are looking forward to deal with companies with good CSR practices (Fombrun and Shanley, 1990).

In addition, the business risk could be reduced as soon as the company able to attract and retain employees (Turban and Greening, 1997). Perhaps, the companies may increase the market share relative to the competitors by providing important information about how the products have been manufactured in a socially or environmentally responsible manner (Miller, 1994). As we know, consumers are willing to pay more for products and services from socially responsible companies (Auger, Devinney and Louveniere, 2003).

Nonetheless, level of awareness of CSR activities is increasing among companies particularly those of developed countries. These companies have become more sensitive to social, environmental and economic issue and stakeholder concerns. It becomes a challenge for the companies as they find ways to improve their performance and integrate social responsibility impacts and financial performance into day-to-day management decision making. However, there are arguments in relation to the relationship between company's corporate social responsibility and their financial performance.

The emerging interests among companies to incorporate CSR in their corporate strategy have attracted studies to examine either the extent of CSR disclosure provided by companies (Ibrahim, Zam Zuriyati, Jamal and Norlia (2013) and Dalilawati, Norhayah and Zakiah (2013)) or the effect of CSR on financial performance of the company relationship (Ioannou and Serafeim, 2012; Inoue and Lee, 2011 and Choi Kwak and Choe, 2010).

Ibrahim, Zam Zuriyati, Jamal and Norlia (2013) carried out a content analysis to examine the importance of corporate social responsibility disclosure (CSRD) of Malaysia consumer products and plantation industry for the year ended 2009. The authors concluded that. Although the number of companies disclosed their CSR activities was high for both industries but the level of disclosure is still low level category in disclosing their CSR activities. It also revealed a gap between the maximum and minimum number of sentences for CSR disclosure in the annual report.

Furthermore, Dalilawati, Norhayah and Zakiah (2013) study, compares the quantity and quality of CSR disclosure disclosed in annual reports of 300 top companies on the main board of Bursa Malaysia between Shariah and non-Shariah approved companies. The analysis is done through a content analysis reflecting the voluntary period (2005-2006) and mandatory period of CSR 
disclosure (2007-2009). Findings from the analysis can be concluded that there is no significant difference in the overall quantity and quality of CSRD disclosed between Shariah and non-Shariah approved companies for the period of 2005-2006. However, through the introduction of the mandatory of CSR disclosures requirement by the Bursa Malaysia in 2007, there are a significance difference particularly on two categories of CSR that is for environment and community related disclosures.

However, the empirical studies have inconclusive, as some studies found a positive correlation; some other determined a negative while others found no correlation at all due to a number of relevant theories and the inconsistencies of research methods. Some researchers reported a positive, negative and neutral impact of CSR on financial performance. The inconsistency may be due to flawed empirical analysis. There are studies indicate a positive relationship (Ioannou and Serafeim, 2012; Inoue and Lee, 2011 and Choi Kwak and Choe, 2010), whilst some studies found a negative and mixed relationship. For instance, Mustaruddin, Norhayah Zulkifli \& Rusnah (2011) found a positive and significant related to the CSR on financial performance but there is limited evidence of the relationship in the long term. Besides, McWilliams and Siegel (2000) did not find any relationship between CSRD and financial performance.

Furthermore, study conducted by Hackston and Milne (1996) on annual reports of 47 companies in New Zealand for the year 1992 is to find evidence on the relationship between CSR disclosure and financial performance. They counted number of sentences related to six types of CSR areas (Environment, human resources, products, energy, community and others) and tested correlated coefficients with profitability measures (ROA and ROE), company size (capitalization and total assets) and industries. It can be concluded that CSR disclosure is significantly associated with size and industry of the company, while there is no correlation with the profitability. Moreover, Everaert, Bouten, Van Liedekerke, De Moor and Christiaens (2009) did find positive and significant relationship between CSR disclosure and profitability and the size of the company on 117 listed Belgium companies for the year 2005.

$21^{\text {st }}$ century owing competitiveness to all national and multinational companies to put the element of CSR in their decision making and to deliver high corporate citizenship. No doubt, to involve in CSR require substantial amount of money and resources to be allocated hence, will lower the company's profitable margin. Therefore, top management of the company need to ensure the resources are being allocated and fully utilized in effective and efficient manner. Although there are lacking of commitment towards CSR practice in emerging countries, specifically in Malaysia, however, it is gradually increase due to emergences of NonGovernmental Organization (NGO) and consumer interest group. In addition, the importance of CSR has triggered. The empirical analysis of the relationship between CSR and CFP has yet to provide a convincing link between variables (Mwangi and Jerotich, 2013). Therefore, this study attempts to contribute in the area and may facilitate more intensive research on CSRD and financial performance, specifically in Malaysia as a developing and emerging country.

The aim of this study is to examine the relationship between CSR disclosure and the company financial performance (CFP) among Malaysian public listed companies (PLCs) specifically focus on consumer product and

Trading and services industry only. The selection of these industries was due to their direct relationship with the society and environment. Furthermore, it is significant to the Malaysian's economy contribution since it contributes more than half of the Malaysian Gross Domestic Product (GDP) (EPU, 2015). 
In particular, the objectives of this study:

a) To examine the extent and quality of CSR disclosure practices between consumer product and trading and services sectors

b) To investigate the relationship between CSR disclosure and financial performance of consumer product sectors

c) To investigate the relationship between CSR disclosure and financial performance of trading and services sectors

\section{DATA AND RESEARCH METHOD}

\section{Sample and Data Size}

This quantitative study involved in examining the annual reports and stand-alone sustainability reports for trading and services and consumer product sector listed on Bursa Malaysia for the year $2003-2013$. The sample selection is done by using simple random sampling. The data for this study were obtained from the web page of Bursa Malaysia and Thompson Reuters data stream. The total population listed on Bursa Malaysia comprises 186 companies for trading and services and 126 companies for consumer product. However, after data cleaning of nonavailability or missing data, it made up of 38 companies and 31 companies used as samples for trading and services and consumer product respectively. The annual reports and stand-alone sustainability reports were employed to gather information as it is the most source of corporate reporting (Jenkins and Yakovlena, 2006) and the most accessible source of information either in hard copy or electronic publications for Malaysian public listed companies (Rusnah, Mustaruddin and Norhayah, 2006).

Based on the research objectives of the study, the following research questions and hypotheses statements are created. The hypotheses of this study are based on the propositions that good CSR practices will directly affect corporate performance in the companies.

Research questions:

a) What is the extent and quality of CSR disclosure practices between consumer product and trading and services sectors? There is difference between the extent and quality of CSR disclosure practices between consumer product and trading and services sectors.

b) What is the relationship between CSR disclosure and financial performance of consumer product sectors?

c) What is the relationship between CSR disclosure and financial performance of trading and services sectors?

\section{Proxies and Measurement of Variables}

\section{Dependent variables}

The dependent variable (DV) used in this study is corporate financial performance (CFP) namely; return on asset (ROA) and Tobin's Q (Q). 
a. Return on asset (ROA): ROA indicates the amount of net profit generated by each ringgit invested in assets. It provides investors with an indicator of how effectively the company is converting asset to invest in net income.

ROA $=$ Net profit $/$ Total assets

b. Tobin's $Q$ ratio $(Q)$ : Based on Cavaco and Crifo (2009), $Q$ ratio is a neutral indicator which is more sensitive to variations "that may be independent of the operations and social activities of and which can affect the market values.

Tobin's Q = (Equity + Total debt) / Total assets

\section{Independent variables}

The independent variables (IV) in this study is measured through CSR disclosure (CSRD), which represents CSR activities disclosure of information in the annual reports or stand-alone sustainability reports. This study applied content analysis to quantify the level of social responsibility information disclosed by selected samples. The disclosure checklist was constructed based on the CSR framework developed by Bursa Malaysia namely, community, environment, marketplace and workplace. The disclosures were rated based on the existence or nonexistence, and the degree of specificity of each item. Haslinda and Lehman (2008) rating approach had been adopted in examining the level of extensiveness in respect of social responsibility disclosure, in which the information was grouped under five categories, namely, general information, qualitative information, quantitative information and a combination of qualitative and quantitative information. These rating scales permit for the measurement of quantified social information (words, sentences or numbers) and also for non-quantifiable disclosures covering graphs, photographs, charts etc.

The total maximum score is set at 288. The maximum for each of the dimensions is 80 for community disclosures, 68 for environment disclosures, 52 for marketplace disclosures and 88 for workplace disclosures. A complete checklist detailing the categories and items of disclosure is attached. Therefore, the development of total CSR disclosure (CSR index),

$$
\mathrm{CSRDi}=\underline{\mathrm{n}} \times 100 \%
$$

$$
\mathrm{N}
$$

Where CSRDI represents the Corporate Social Responsibility Disclosure Index, $\mathrm{n}$ is the number of items which were disclosed by the companies for each of the CSR dimension and $\mathrm{N}$ indicates number of items expected disclosed by the companies.

\section{Control Variables}

a. Company size: It is relevant to consider company size as a control variable because evidence proved that smaller companies may not demonstrate as many socially responsible behaviors as compared to larger companies. According to Waddock and Graves (1997), as they mature and grow, companies attract more attention from external constituents and need to respond more openly to stakeholders demands. For the purpose of this study, the company size is measured through the total assets of company to show the company's liquidity. By including company size as the control variable, it allows the identification of factors other than CSR could influence the CSR performance measure. 
b. Earnings per share (EPS): EPS shows the earnings of how much profit is earned during the period of one year on behalf of each outstanding shares of common stock. Big companies might generate greater income as compared to a smaller company who be doing better in terms per unit of ownership. Thus, EPS is a better performance indicator on how efficient a company in generating earnings from each of the outstanding shares of common stock.

EPS $=$ Net income/Number of outstanding shares of common stock

\section{Statistical Analysis}

In lieu to determine the relationship between CSR disclosure and organizational performance in terms of financial performance, a different statistical analysis were used. The Eviews software version 9.0 was used in the analyses of the extent and quality of the information disclosed in the annual reports or stand-alone sustainability reports. The measurement of central tendency provides the mode, median and mean of data collected.

Furthermore, the regression of model to examine the relationship between variables is using panel data which is the observation on cross sectional and time series. For the purpose of this study, Generalized Least Squared (GLS) method is used. The fixed effect (FE) and random effect (RE) model is employed in order to differentiate between models; whether unabsorbed individual effects are correlated with the regressors which is the case of fixed effects, or not in the models, as in the case of the random effects model. In a case of FE model, the intercept in the regression model is allowed to differ among individuals in recognition of the fact that each individual or cross section unit may have some special characteristics of its own. As a result, the Hausman test will be conducted in choosing which model is more precise. The model specification are as follows:

$$
\begin{aligned}
& \text { Model } 1: \mathrm{ROA}_{\mathrm{i}}=\mathrm{c}+\mathrm{COM}+\mathrm{ENV}+\mathrm{MKT}+\text { WORK } \\
& \text { Model } 2: \mathrm{Q}_{\mathrm{i}}=\mathrm{c}+\mathrm{COM}+\mathrm{ENV}+\mathrm{MKT}+\text { WORK } \\
& \text { Where, for company } ; \\
& \text { ROA = Return on asset } \\
& \mathrm{Q}=\text { Tobin's Q ratio } \\
& \mathrm{COM}=\text { Community disclosure } \\
& \mathrm{ENV}=\text { Environment disclosure } \\
& \text { MKT = Marketplace disclosure } \\
& \text { WORK = Workplace disclosure }
\end{aligned}
$$

\section{ANALYSIS AND FINDINGS}

\section{Descriptive Findings}

Table 4.1 provides the descriptive findings of CSR dimension of CSR disclosure disclosed in the annual reports or stand-alone sustainability reports of the sample. The analysis found that 
the total CSR disclosure, CSR index (CSRD) for trading and services companies was 0.05 while the minimum and the maximum values were 0 and 0.70 respectively. Amongst the four CSR dimension, community involvement had the highest mean score of 0.07 , followed by the workplace (0.06) and environment (0.54). The least mean score was related to marketplace (0.04).

\begin{tabular}{|c|c|c|c|c|c|c|c|c|c|c|}
\hline \multirow[t]{2}{*}{ CSR Disclosures } & \multicolumn{5}{|c|}{ Trading \& Services } & \multicolumn{5}{|c|}{ Consumer Products } \\
\hline & Obs & Min & Max & Mean & SD & Obs & Min & Max & Mean & SD \\
\hline Community & 418 & 0.00 & 0.45 & 0.07 & 0.09 & 341 & 0.00 & 0.57 & 0.06 & 0.09 \\
\hline Environment & 418 & 0.00 & 0.70 & 0.05 & 0.09 & 341 & 0.00 & 0.79 & 0.06 & 0.13 \\
\hline Marketplace & 418 & 0.00 & 0.50 & 0.04 & 0.08 & 341 & 0.00 & 0.48 & 0.05 & 0.08 \\
\hline Workplace & 418 & 0.00 & 0.61 & 0.06 & 0.09 & 341 & 0.00 & 0.64 & 0.06 & 0.11 \\
\hline CSR index & 418 & 0.00 & 0.44 & 0.05 & 0.07 & 341 & 0.00 & 0.56 & 0.06 & 0.09 \\
\hline
\end{tabular}

Table 4.1 Descriptive statistics for CSR dimension of CSR disclosure

In respect to descriptive findings for consumer products, the total of CSR disclosure, CSR index (CSRi) was 0.06 while the minimum and the maximum values were 0 and 0.79 respectively. The community involvement, environment and workplace had the highest mean score of 0.06 and the least mean score was related to marketplace (0.05).

These results are consistent with Ibrahim, Zam Zuriyati, Jamal and Norlia (2013) who revealed that in terms of number of sentences, consumer products companies disclosed more information compared with plantation industry of 1,885 sentences and 636 sentences respectively.

Furthermore, Table 4.2 presents the frequency of each of CSR disclosure disclosed in the annual reports or stand-alone sustainability reports. Consistent with the mean score outcomes in Table 4.1, trading and services companies had a high frequency of disclosure in respect to community contribution information (32\%), followed by workplace (26\%) and environment $(22 \%)$. The least frequent disclosure was related to marketplace information (20\%). These findings are consistent with Mohamad Hafiz, Jamaliah and Nuruu Ain (2015) revealed that the highest frequency score was community disclosure.

\begin{tabular}{|l|c|c|c|c|}
\hline \multirow{2}{*}{ CSR Disclosures } & \multicolumn{2}{|c|}{ Trading \& Services } & \multicolumn{2}{c|}{ Consumer Products } \\
\cline { 2 - 5 } & Obs & $\begin{array}{c}\text { Total } \\
\text { CSRD (\%) }\end{array}$ & Obs & $\begin{array}{c}\text { Total } \\
\text { CSRD } \\
\text { (\%) }\end{array}$ \\
\hline Community & 418 & 32 & 341 & 25 \\
\hline Environment & 418 & 22 & 341 & 26 \\
\hline Marketplace & 418 & 20 & 341 & 22 \\
\hline Workplace & 418 & 26 & 341 & 27 \\
\hline
\end{tabular}

Table 4.2 Frequency of CSRD for each CSR dimension

For consumer products industry, the highest frequency of disclosure was in regard to workplace disclosure $(27 \%)$, followed by the environment $(26 \%)$ and community involvement $(25 \%)$. However, similar with trading and services industry, they disclosed fewer information on marketplace engagement $(20 \%)$. Such a result implied that the motivation for marketplace disclosure practice in Malaysia was at inconsistency. The evident low level of CSR disclosure on marketplace engagement are due to absence of a appropriate reporting framework, the costs related to the reporting process, doubts of how readers will respond as well as the absence of government and primary stakeholders' pressure (Thompson and Zakaria, 2004). 
A Spearman Rank Order (SRO) test was performed to test the existence high inter-correlation among the independent variables. Based on the Spearman correlation results revealed that none of the correlation results among the independent variables exceed the 0.70 cut-off points as indicated by Sekaran and Bougie (2010). Moreover, the unit root test of Levin, Lin and Chu (LLC) and Philips Pherron (PP) hypothesize that all variables rejected the null hypothesis and are significant at 1 per cent level of confidence. The rejection of null hypothesis indicates that the data series is stationary at first difference. Hence, regression of analysis was conducted by using the transformed data at first difference.

\section{Relationship between CSR disclosure and CFP}

The estimation findings of the relationship between CSR disclosure and CFP are revealed in Table 4.3. There are two dependent variables which was used to measure the relationship; return on asset (ROA) and Tobin's $Q$ ratio (T'Q). As a result, for trading and services industry, Model 1 when ROA as the dependent variable, the random effect (RE) is more perfect than the fixed effect (FE) model since the Hausman test is insignificant. It is presumed that the variation across entities to be random and uncorrelated with the predictor variables included in the model. The signs of independent variables have mixed findings except for the total size (LTA) have a negative relationship. The Adjusted $\mathrm{R}^{2}$ shows that financial performance is explained by total CSR disclosure (CSRD) by 23.7 per cent only. In Model 2 when Tobin's Q ratio (T'Q) used as the dependent variable, it is also found that the random effect (RE) is more appropriate than the fixed effect (FE) model since the Hausman test is insignificant. In general, the CSR disclosure (CSRD) is positive and significantly associated to financial performance at least at 5 per cent level. Adjusted $\mathrm{R}^{2}$ shows that financial performance is explained by the CSRD and other explanatory variables with estimation at 25 per cent.

\begin{tabular}{|l|c|c|c|c|}
\hline & \multicolumn{2}{|c|}{ Trading \& Services } & \multicolumn{2}{c|}{ Consumer Product } \\
\hline Variable & $\begin{array}{c}\text { Model 1 } \\
\text { ROA }\end{array}$ & $\begin{array}{c}\text { Model 2 } \\
\text { T'Q }\end{array}$ & $\begin{array}{c}\text { Model 1 } \\
\text { ROA }\end{array}$ & $\begin{array}{c}\text { Model 2 } \\
\text { T'Q }\end{array}$ \\
\cline { 2 - 5 } & $\begin{array}{c}\text { RE Model } \\
\text { Coefficien } \\
\mathrm{t} \\
\text { (p-value) }\end{array}$ & $\begin{array}{c}\text { RE Model } \\
\text { Coefficient } \\
\text { (p-value) }\end{array}$ & $\begin{array}{c}\text { RE Model } \\
\text { Coefficient } \\
\text { (p-value) }\end{array}$ & $\begin{array}{c}\text { RE Model } \\
\text { Coefficient } \\
\text { (p-value) }\end{array}$ \\
\hline C & $\begin{array}{c}\mathbf{0 . 0 8 6 1 8} \\
(0.0127)^{* *}\end{array}$ & $\begin{array}{c}\mathbf{0 . 0 0 8 6} \\
(0.0000)^{* * *}\end{array}$ & $\begin{array}{c}\mathbf{0 . 0 7 7 1} \\
(0.0000)^{* * *}\end{array}$ & $\begin{array}{c}\mathbf{0 . 0 0 8 0} \\
(0.0000)^{* * *}\end{array}$ \\
\hline CSRD & $\begin{array}{c}\mathbf{0 . 0 5 0 4} \\
(0.0105)^{* *}\end{array}$ & $\begin{array}{c}\mathbf{0 . 0 0 2 3} \\
(0.0352)^{* *}\end{array}$ & $\begin{array}{c}\mathbf{0 . 0 3 0 0} \\
(0.0315)^{* *}\end{array}$ & $\begin{array}{c}\mathbf{- 0 . 0 0 1 4} \\
(0.0373)^{* *}\end{array}$ \\
\hline TA & $\begin{array}{c}\mathbf{- 0 . 0 0 6 0} \\
(0.0285)^{*} \\
*\end{array}$ & $\begin{array}{c}\mathbf{- 0 . 0 0 0 2} \\
(0.0891)^{*}\end{array}$ & $\begin{array}{c}\mathbf{- 0 . 0 2 1 4} \\
(0.0140)^{* *}\end{array}$ & $\begin{array}{c}\mathbf{- 0 . 0 0 0 2} \\
(0.0477)^{* *}\end{array}$ \\
\hline EPS & $\begin{array}{c}\mathbf{5 . 8 4 7 6} \\
(0.0177)^{*} \\
*\end{array}$ & $\begin{array}{c}\mathbf{0 . 0 4 0 5} \\
(0.0453)^{* *}\end{array}$ & $\begin{array}{c}\mathbf{0 . 0 8 4 2} \\
(0.0336)^{* *}\end{array}$ & $\begin{array}{c}\mathbf{0 . 0 0 0 5} \\
(0.0377)^{* *}\end{array}$ \\
\hline Adjusted R ${ }^{2}$ & 0.2368 & 0.2500 & 0.3954 & 0.2058 \\
\hline F- statistic & 14.7886 & 0.6483 & 0.9398 & 0.3222 \\
\hline Durbin- & 2.033 & 1.054 & 1.4732 & 1.056 \\
Watson & & & & \\
\hline
\end{tabular}

Note: $\quad * * *$ Significant at $1 \%$ level, $* *$ Significant at $5 \%$ level, $*$ Significant at $10 \%$ level

Table 4.3 Relationship between CSR disclosure and financial performance using panel data 
The findings showed that correlation between CSR disclosure and financial performance for consumer product industry, Model 1 when ROA as the dependent variable, the random effect (RE) is more precise than the fixed effect (FE) model. The signs of independent variables have mixed findings as for the total size (LTA) have a negative relationship. The Adjusted $\mathrm{R}^{2}$ shows that financial performance is explained by total CSR disclosure (CSRD) by 39.5 per cent only. In Model 2 when Tobin's $Q$ ratio (T'Q) used as the dependent variable, it is also found that the random effect (RE) is more appropriate than the fixed effect (FE) model since the Hausman test is insignificant. In general, the CSR disclosure (CSRD) is positive and significantly associated to financial performance at least at 5 per cent level. Adjusted $\mathrm{R}^{2}$ shows that financial performance is explained by the CSRD and other explanatory variables with estimation at 20.6 per cent.

The detail analysis which is based on the dimension of CSRD score is revealed in Table 4.4. The measurement for the financial performance is retain with ROA and Tobin's $Q$ ratio (T'Q) as the dependent variable. In conclusion, the (RE) is more precise than the fixed effect (FE) model since the hypothesis testing accept the null hypothesis.

It is found that CSRD for trading and services industry, Model 1 when ROA the dependent variable, community $(\mathrm{COM})$, environment (ENV) and marketplace (MKT) is positive and significantly related to financial performance whilst workplace (WORK) is negatively significant associated with financial performance. For Model 2, when T'Q ratio used as the dependent variable, community (COM), environment (ENV) and marketplace (MKT) and workplace (WORK) is positive and significantly related to financial performance, whilst size of the company (TA) is negatively significant associated with financial performance.

\begin{tabular}{|c|c|c|c|c|}
\hline & \multicolumn{2}{|c|}{ Trading \& Services } & \multicolumn{2}{|c|}{ Consumer Product } \\
\hline \multirow[t]{2}{*}{ Variable } & $\begin{array}{l}\text { Model } 1 \\
\text { ROA }\end{array}$ & $\begin{array}{c}\text { Model } 2 \\
\text { T'Q }\end{array}$ & $\begin{array}{l}\text { Model } 1 \\
\text { ROA }\end{array}$ & $\begin{array}{c}\text { Model } 2 \\
\text { T'Q }\end{array}$ \\
\hline & $\begin{array}{c}\text { RE Model } \\
\text { Coefficient } \\
\text { (p-value) }\end{array}$ & $\begin{array}{c}\text { RE Model } \\
\text { Coefficient } \\
\text { (p-value) }\end{array}$ & $\begin{array}{c}\text { RE Model } \\
\text { Coefficient } \\
\text { (p-value) }\end{array}$ & $\begin{array}{c}\text { RE Model } \\
\text { Coefficient } \\
\text { (p-value) }\end{array}$ \\
\hline $\mathrm{C}$ & $\begin{array}{c}\mathbf{0 . 1 1 4 2} \\
(0.0000)^{* * *}\end{array}$ & $\begin{array}{c}\mathbf{0 . 0 0 8 6} \\
(0.0000)^{* * *}\end{array}$ & $\begin{array}{c}\mathbf{0 . 0 7 3 8} \\
(0.0000)^{* * *}\end{array}$ & $\begin{array}{c}\mathbf{0 . 0 0 8 0} \\
(0.0000)^{* * *}\end{array}$ \\
\hline $\mathrm{COM}$ & $\begin{array}{c}\mathbf{0 . 0 1 8 4} \\
(0.0081)^{* * *}\end{array}$ & $\begin{array}{c}\mathbf{0 . 0 0 0 8} \\
(0.0086)^{* * *}\end{array}$ & $\begin{array}{c}\mathbf{0 . 0 4 5 3} \\
(0.0090)^{* * *}\end{array}$ & $\begin{array}{c}\mathbf{0 . 0 0 1 4} \\
(0.0305)^{* *}\end{array}$ \\
\hline ENV & $\begin{array}{c}\mathbf{0 . 0 1 9 1} \\
(0.0055)^{* * *}\end{array}$ & $\begin{array}{c}\mathbf{0 . 0 0 0 5} \\
(0.0073)^{* * *}\end{array}$ & $\begin{array}{c}\mathbf{0 . 1 2 4 9} \\
(0.0038)^{* * *}\end{array}$ & $\begin{array}{c}\mathbf{0 . 0 0 0 2} \\
(0.0066)^{* * *}\end{array}$ \\
\hline MKT & $\begin{array}{c}\mathbf{0 . 0 1 3 8} \\
(0.0069)^{* * *}\end{array}$ & $\begin{array}{c}\mathbf{0 . 0 0 0 8} \\
(0.0072)^{* * *}\end{array}$ & $\begin{array}{c}\mathbf{- 0 . 0 5 5 3} \\
(0.0022)^{* * *}\end{array}$ & $\begin{array}{c}\mathbf{0 . 0 0 0 5} \\
(0.0077)^{* * * *}\end{array}$ \\
\hline WORK & $\begin{array}{c}\mathbf{- 0 . 0 1 3 5} \\
(0.0071)^{* * *}\end{array}$ & $\begin{array}{c}\mathbf{0 . 0 0 0 2} \\
(0.0006)^{* * *}\end{array}$ & $\begin{array}{c}\mathbf{0 . 1 5 3 3} \\
(0.0021)^{* * *}\end{array}$ & $\begin{array}{c}\mathbf{- 0 . 0 0 0 4} \\
(0.0154)^{* *}\end{array}$ \\
\hline TA & $\begin{array}{c}\mathbf{- 0 . 0 1 1 6} \\
(0.0000)^{* * *}\end{array}$ & $\begin{array}{c}\mathbf{- 0 . 0 0 0 2} \\
(0.0133)^{* *}\end{array}$ & $\begin{array}{c}\mathbf{- 0 . 0 1 8 5} \\
(0.0607)^{*}\end{array}$ & $\begin{array}{l}3.65 E-05 \\
(0.0909)^{*}\end{array}$ \\
\hline EPS & $\begin{array}{l}\mathbf{1 1 . 9 9 0 0} \\
(0.0000)\end{array}$ & $\begin{array}{c}\mathbf{0 . 0 4 1 0} \\
(0.0452)^{* *}\end{array}$ & $\begin{array}{c}\mathbf{0 . 0 7 5 8} \\
(0.0909)^{*}\end{array}$ & $\begin{array}{c}\text { 8.42E-05 } \\
(0.6768)\end{array}$ \\
\hline Adjusted $\mathrm{R}^{2}$ & 0.2147 & 0.2398 & 0.3103 & 0.1905 \\
\hline F- statistic & 20.1450 & 0.3222 & 1.536 & 0.9699 \\
\hline $\begin{array}{l}\text { Durbin- } \\
\text { Watson }\end{array}$ & 1.6471 & 1.056 & 1.336 & 1.755 \\
\hline
\end{tabular}

Table 4.4 Relationship between CSR disclosure and financial performance using panel data 
However, the adjusted $\mathrm{R}^{2}$ at 21.5 per cent and 23.9 per cent is respectively explained the financial performance through CSRD measurement.

In a same time, for consumer product industry, Model 1 when ROA the dependent variable, it shows that community (COM), environment (ENV) and workplace (WORK) is positive and significantly related to financial performance, similar with the trading an services industry. However, dimension for marketplace (MKT) is negatively significant associated with financial performance. For Model 2, when T'Q ratio used as the dependent variable, all the CSR dimensions; community (COM), environment (ENV) and marketplace (MKT) and workplace (WORK) is positive and significantly related to financial performance.

\section{DISCUSSION AND CONCLUSION}

This study attempts to examine the comprehensiveness of CSR disclosure disclosed by the companies via the annual report or stand-alone sustainability report. Generally, it can be concluded that public listed companies in Malaysia have started to realize the need and importance of disclosing social responsibility information as a medium to communicate with stakeholders and community. It indicated a development signal for CSR disclosure in Malaysia when there are companies who disclose the CSR information in a special report namely; standalone sustainability report. However, many companies were still at low level in disclosing the CSR activities which score below 50 per cent for each dimension for both of the industry. Furthermore, it revealed that there was a gap between the minimum and maximum of CSR disclosure in the report.

From the study it can be concluded that CSRD have an association with the financial performance (CFP). For instance, both of the industry show a positive and significantly relationship between community (COM) and CFP. It shows that there is no negative response from stakeholders when the companies spend specific financial resources to support the society development. The companies believed that in order to maintain the company's reputation and image, it is imperative for them to gain support and being recognize by the society. This includes education sponsorship, rural area development, philanthropic events, national events and many more to mention.

Although it is believed that engagement in environment matters may cause higher cost and a lot of environmental management guidelines to follow, it is found that environment (ENV) and marketplace (MKT) dimension is positive and significantly related to CFP for both industry. It indicate that involvement on environment issues and investing on product development help to add sufficient value to the reputation of the companies.

The workplace (WORK) dimension is positively significant associated with the CFP when ROA as dependent variable for consumer product. It can be concluded that, investing on employee's development and incentives scheme able to increase the morale of employees to put high commitment in their productivity. These include loyalty award, training and development for employees, health and safety and others (Waddock and Graves, 1997). However, the workplace (WORK) dimension have a negative associated with the CFP for trading and services.

Corresponding author's email: nor_1143@yahoo.com 
In general, the findings confirmed that there is limited evidence of a significant relationship between CSRD and CFP in a long-term period. This is also revealed that there is still limited number of companies consistently in disclosing CSR activities in the reports. Hence, this results may be inconsistent for both industry due to different industry and companies may contribute and disclose their CSR activities in a different way. The involvement of CSR activities may also may be determined by the pressure from the shareholders or authority body and policy makers. The government agencies could also support companies to involve in CSR activities and later disclose them.

The limitation of this study is on the inconsistency of results obtained by using different proxy for the CFP for two different industry. In addition, the sample is taken at randomly regardless the size of the company. This include small size of company in the industry who assume that disclosing CSR activities could affect their cash flows reporting. However, the nature of Malaysia guidelines does not have any specific amount or area for the company to disclose CSR activities and this make content analysis more viable option.

\section{REFERENCES}

Auger, P., Devinney, T.M., and Louveniere, J.J. (2003). What will consumers pay for social product features? Journal of Business Ethics, vol. 43, no.3, pp. 281-304

Cavaco, S. And Crifo, P (2009). The CSP-CFP missing link: Complementarity between environmental, social and governance practices? Journal of Economic Literature

Choi, J., Kwak, Y., \& Choe, C., (2010). Corporate Social Responsibility and Corporate Financial Performance: Evidence from Korea. Australian Journal of Management, vol. 35, no.3, pp. 291-311

Dalilawati Zainal, Norhayah Zulkifli and zakiah Salleh (2013). Corporate social Responsibility in Malaysia: A Comparison between Shariah and Non-Shariah Approved Firms, Middle-East Journal of Scientific Research, vol. 15, no. 7, pp. 1035-1046

Everaert, P., Bouten, L., Van Liedekerke, L., De Moor, L. and Christiaens, J. (2009). Discovering Patterns in Corporate Social Responsibility (CSR) Reporting: A transparent framework based on Global Reporting Initiatives (GRI) Sustainability Reporting Guidelines. Working papers of Faculty of Economics and Business Administration, Ghent University, Belgium

Haslinda, Y., and Lehman, G. (2008), International differences on corporate environmental accounting developments: A comparison between Malaysia and Australia accounting and finance in transition, vol.4, Greenwich University press, pp. 92-124

Ibrahim Thamby Chek, Zam Zuriyati Mohamad, Jamal Yunus and Norlia Mat Nawawi (2013). Corporate Social Responsibility (CSR) Disclosure in Consumer Products and Plantation Industry in Malaysia, American International Journal of Contemporary Research, vol. 3, no. 5, pp. 118-125 
Inoue, Y \& Lee, S (2010). 'Effects of different dimensions of Corporate Social Responsibility on corporate financial performance in tourism-related industries', Tourism Management, vol.32, no.2, pp. 790-804

Ioannuo, I. \& Serafeim, G (2012). What drives corporate social performance? International evidence from Social, Environmental and Governance Scores, HBS Working Paper

Jenkins, H \& Yakovleva, N (2006). 'Corporate Social Responsibility in the mining industry: Exploring trends in social and environmental disclosure', Journal of Cleaner Production, vol.14, no.3, pp.271-84

Mahoney, L.S. \& Robert, R.W (2007). Corporate Social Performance, financial performance and institutional ownership in Canadian firms, Accounting Forum, vol. 31, pp. 233-253

Margolis, J.D., Elfenbein, H. \& Walsh, J.P. (2007). Does it pay to be good? A Meta analysis and redirection of reserach on the relationship between Corporate Social and financial performance, working paper

McWilliams, A., Siegel, D.S., \& Wright. P.M, (2000). Corporate Social Responsibility and Financial Performance: Correlation or misspecification? Strategic Management Journal, vol. 21, no.5, pp. 603-609

Miller, J.G. (1994). Cultural Diversity in the morality of caring. Individually oriented versus duty-based interpersonal moral codes, Cross Cultural Research, vol. 28, no.1, pp. 3-39

Mustaruddin Saleh (2009). Corporate social responsibility disclosure in an emerging market: A longitudinal analysis approach. International Business Research, vol. 2 no.1, pp. 131-141

Mustaruddin Saleh, Norhayah Zulkifli \& Rusnah Muhamad (2011). Looking for evidence of the relationship between corporate social responsibility and corporate financial performance in an emerging market, Asia-Pacific Journal of Business Administration, vol. 3 no.2, 2011, pp. 165-190

Mwangi, C. I., and Jerotich, O.J. (2013). The relationship between corporate social responsibility practices and financial performance of firm in manufacturing, construction and allied sector of the Nairobi Securities Exchange. International Journal of Business, Humanities and Technology, vol. 3(2)

Norhawani, Mustaffa \& Norashfah (2011). CSR disclosures and its determinants: evidence from Malaysian government link companies, Social Responsibility Journal, vol. 7, no.2, pp. $181-201$

Orlitzky, M., James, G., Schmidt, F.L., \& Rynes, S.L. (2003). Corporate Social Responsibility and Financial Performance: A Meta-Analysis, Organization Studies, vol. 24, pp. 403441

Othman, S., Darus, F. and Arshad, R. (2011). The influence of coercive isomorphism on corporate social responsibility reporting and reputation. Socially responsibility Journal, vol.1, no. 1, pp.119-132

Corresponding author's email: nor_1143@yahoo.com 
Ruf, B.M., Muralidhar, K., Brown. R.M., Janney, JJ \& Paul, K. (2001). An empirical investigation of the relationship between change in corporate social performance and financial performance: A stakeholder theory perspective, Journal of Business Ethics, vol. 32 , pp. $143-156$

Sheveta Kapoor \& Sandhu, H.S (2010). Does it pay to be socially responsible? An empirical examination of impact of corporate social responsibility on financial performance. Global Business Review, vol. 11, no.85, pp. 185-208

Thompson, P. and Zurina, Z. (2004). Corporate social responsibility reporting in Malaysia progress and prospects. Journal of Business Corporate Citizenship, vol. 13, pp. 125136

Tsoutsoura, M. (2004). Corporate social responsibility and financial performance: In possession of Centre of Responsible Business, Working paper series, Paper 7, University of California, Berkeley

Turban, D.B. and Greening, D.W. (1997). Corporate Social Performance and Organizational Attractiveness to Perspective Employees, Academy of Management Journal, pp. 658672 